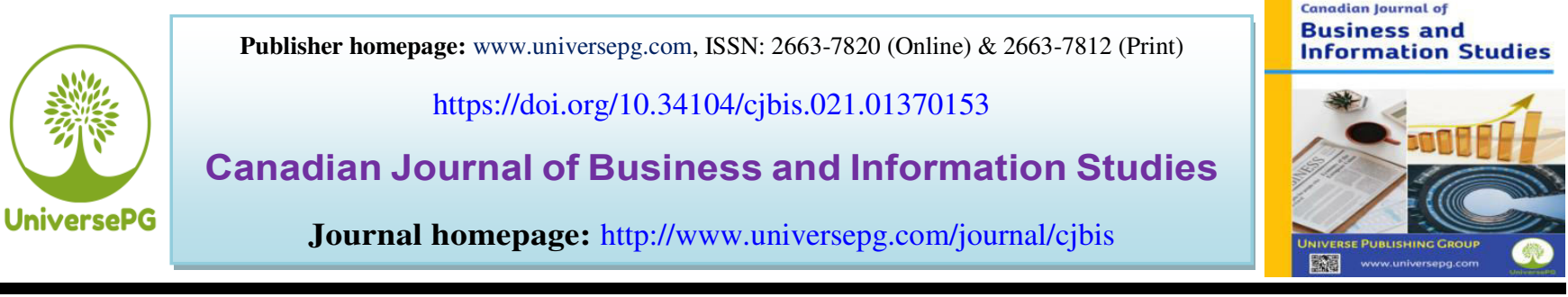

\title{
Globalization and Its Impact on Women's Empowerment in Bangladesh
}

\author{
Soma Dhar* \\ Department of Economics, University of Chittagong, Bangladesh \\ *Correspondence: soma.chowdhury7@yahoo.com (Soma Dhar, PhD Student, Department of Economics, University of \\ Chittagong, Bangladesh).
}

\begin{abstract}
This research aims to investigate the impact of globalization on women's empowerment in Bangladesh. Like many other countries, Bangladesh also integrated with the rest of the world through globalization. Empirical studies on the impact of globalization on women's empowerment in Bangladesh circumstances are rare. Many studies to date have adjudicated to review the positive and negative effects of globalization on women. The study highlights the impact of globalization on women's empowerment in Bangladesh in three ways. Firstly, the study draws application to traverse the testimony of women's empowerment by examining the initiatives (National Women Development Policy) taken by the government to levitate the status of women in society through their participation in economic and social activities and discusses the limitations and pivotal suggestions for the policy. Secondly, the study explains the positive and negative effects of globalization on women's lives in Bangladesh. And finally, for the quantitative analysis, the study shows different scatter plots to establish the relationship between globalization and women empowerment as the KOF Index and the GGG Index, and the SIGI Index using time series data for the period of (2007-2017).
\end{abstract}

Keywords: Globalization, KOF Index, GGG Index, SIGI Index, and National women development policy.

\section{INTRODUCTION:}

As a buzzword, globalization has come to dominate the world since the 1990s. Generally, it is a process of revealing world trade, development of advanced means of communication, internationalization of financial market, and more generally, increased mobility of persons, goods, assets, information, and ideas. Rosa Luxemburg coined this word in 1870 by giving the internationalization of capital a new name. At the dawn of the $21^{\text {st }}$ century, globalization practiced designating as a restricted issue. The world economies have welcomed the moving towards globalization by many as an opportunity for women's empowerment. This phenomenon has led women to play an increasingly dispensable role in international, national, and household economies. The effects of globalization will not foster if women, as new actors on the world scene, are not UniversePG I www.universepg.com pivotal role players in economic, social, political, and family life. In principle, globalization also does or ought to challenge the traditional inferior status of women is contradicted by the relatives of continuing male command of major social institutions. Thus, it is obligated to review and rethink the degree to which women today have genuine biopower, economic power, cultural power, and power in making and executing political decisions.

The empowerment of women is now a modernized global issue. Moreover, this term used for improving women's condition may connect to any disadvantaged group of society for returning them to the same level of forwarding section (Huq, 2016). In most parts of the world, we found discrimination against women in social, economic and cultural, and political aspects 
compared to their male counterparts. Therefore, the stress placed on women's empowerment for more satisfying their lives as they establish almost half of the world's population. Sustainable development is possible only when women will associate with the mainstream development process. Women's empowerment can help promote humanity to a great extent. Women's empowerment refers to a pre-condition for their development. However, it has several dimensions, such as social, economic, and political, which can be perceived and attained at individual and collective levels. These dimensions are interrelated, implying the actions promoting one portion strengthen the values of the other portions (Haider and Akhtar, 1999). (Afshar and Barreintos, 1991) purser that globalization influences women in the most assorted aspects of their lives and the remotest expanses of the world. The consequences have been sundry and contradictory, inclusionary, and exclusionary. Globalization is a multi-dimensional manner of economic, political, sociocultural, and ideological diversity. It has a diverse impact on women's rights. On one side, globalization has led to increasing infringements of women's rights in extensive measure due to the withering away of the benefit palmist state, the feminization of impoverishment, and the spiritual fundamentalisms, and new forms of militarism and conflict. On the other hand, features of globalization have furnished women with increasing facilities to work to dictate their rights in solidarity at the national, regional, and international levels. (Islam, 2009) pointed out that Bangladesh moved to welcome the wave of globalization in the 1990 s, after an uncertain inauguration in the mid1980s. In 1975, Bangladesh actively had participated in the first World Women Congress in Mexico. The mainstreaming of the Bangladesh women's progress was a movement that waged outside the country. The terrain of the present level of women's development in Bangladesh formed with this dynamism. The $2^{\text {nd }}$ Women Convention convened in Copenhagen in 1980, the 3rd World Women Convention held in Nairobi (1985), and the 4th World Women Convention in 1994 at Jakarta Declaration. The principal theme of these strategies centered on women's political participation (Chowdhury, 1994). So, the issue of women's empowerment (political) is one of the current and significant issues thoroughly considered in the world trying UniversePG I www.universepg.com to strengthen women in the mainstream regarding the decision-making process. Chowdhury, (1994) prepares a sound inspection of the structure and arena of politics and women's political rights. Pointing out the and rocentrism of politics and the requirement for women's participation and partnership in politics, the author associates the causes behind the low rate of women's political participation in all parts of the world. In light of this global view, the author then focuses on Bangladesh and suggests introducing a minimum quota system in the structure and hierarchy of political parties to ensure an equal representation of women in politics. In Bangladesh, where employment and earning opportunities are seriously low and highly involve hard physical work in agriculture and manufacturing, the latter typically requires staying away from home. This division of labor accords with the doctrine of comparative advantage (Hossain et al., 2012).

Women's participation in the labor force has increased compared to men albeit; women are highly in low-end jobs. Sultana, (2014) uttered that the readymade garment sector continued to be the largest, employing women, albeit mainly as frontline unskilled workers. Though women work in some new occupations, their engagement in the non-farm sector has not reached the target. $68.84 \%$ of women were engaged in the agriculture sector, followed by the services area (21.89\%) and the industry sector (13.32\%) in 2010. The Labor Force Survey (LFS) 2010 found an increase in female labor force participation from $29.2 \%$ in $2005 / 6$ to $36 \%$ in 2010. According to ILO report, female labor force participation rate in Bangladesh has increased to 36.3 percent in 2017 from 33.2 percent in 2016 whereas the male participation rate increased slightly to 80.7 percent in 2017 from 79.4 percent in 2016 (Daily Star, 2018). In Bangladesh, the number of operating women is doubled to 18.6 million in $2016-17$ from 16.2 million in 2010 (Chaity, 2018).

Globalization provided new opportunities for women in Bangladesh. The leading industry in Bangladesh is apparel manufacturing and exporting. In this industry, women became the dominant workforce employed. To allow women a position in the working world is a positive succession. This situation could be possible in countries like the US and Europe albeit, in Bangladesh, this is not the case. Agreeing that working women in 
Bangladesh is a good step would be the failure to recognize that women are being placed into this new labor category because they can easily be controlled and manipulated.

Bangladesh has made considerable development regarding women's empowerment. Women are actively involved in family planning choices and have achieved a voice in family decision-making because maternal mortality rates and fertility rates have drastically declined. More and more, women are becoming involved in political roles like holding seats in parliament which tends an even greater voice for women's issues. Nevertheless, much work still needs to be consummate. Social and institutional hurdles remain in place to serve as an impediment to the ability of women to reach full empowerment. Inequality in gender is still much a part of this patriarchal society. Women still find it hard to obtain an education, health care, employment, and safety from the threat of violence.

\section{Conceptualizing Women Empowerment}

The theory of empowerment coined by Paulo Freire (1921-1997), a Brazilian scholar, championed the concept of the Pedagogy of the Oppressed. According to Freire, (1972), empowerment is a method by which an oppressed person perceives the structural conditions of his oppression and is subsequently able to take action against his oppressors. Bosherup, (1970) pioneers Women's Role in Economic Development brought greater attention to the importance of women's role in agricultural economies and the shortage of adjustment of development projects with this reality. Tolentino, (2016) notes that empowerment supplicates power while signifying the lack of it. The justification of empowerment looks like an explorer supporting a claim on new territory with a white flag. Empowerment means delegation of power and authority. Women empowerment means delegation of power, authorization, and permission to women to decide matters relating to them. Batliwala, (2007) broadened the concept of women empowerment as a collective process to understand it as an individual process of selftransformation. Rahman, (2013) explains the concept through liberal, structural and cultural perspectives. From a liberal perspective, the women's empowerment strategy suffers from three delusions such as exclu-

UniversePG I www.universepg.com sionary bias, adversarial orientation, and subversive logic (Sharma, 2000). From a structural panorama, the issue negotiates women as a homogenous category, an identical mass (Sharma: ibid). From a cultural viewpoint, the strategy can denounce its pronounced western ethnocentrism (Sharma: ibid). Women empowerment is a process to recreate them perfectly what they can be, can do, and realize in a circumstance that they were previously declined, without requiring permission from another source. World Bank (2001) affirms (rights, resources, and voice) of women, a view repeated by Chen (1992), stresses (resources, attitudes, relationships, and power), while Kabeer (1999) highlights (resources, agency, and achievements) as parameters of women empowerment. Parveen, (2008) discussed women's empowerment regarding economic control and access to resources, power within the household (Mason and Smith 2003), a process of gaining control (Sen, 1997), and involvement in politics (Inglehart and Norris, 2003). In the early 20th century, Begum Rokeya Sakhawat Hossain commenced the mission of women's empowerment and women's rights in Bangladesh. She tried to display her philosophy for the necessity of women's education and equality which was even a dream to the other women with her writings. What she did to increase women's education. During that time, there was almost no education among Bangladeshi Muslim women.

\section{Dimensions and Determinants of Women Em- powerment}

Three dimensions of empowerment sketched by Kabeer, (1995) explain these as the pathways through which empowerment transpires. The first dimension is resources, which introduces the conditions of choice, meaning one appraises and can choose alternative options or the pre-conditions. The second dimension is an agency, which assigns to a process by which one differentiates between calculated life opportunities and second-order choices and makes choices in either platform. These two dimensions (resources and agency) are considered an encouragement for empowerment, which is often connected to control, awareness, or power. And finally, the third dimension is achievements, which refers to the effect of the choices made. One dimension can attend to changes in the others. The determinants of women empowerment are: 


\section{Economic Empowerment}

Economic empowerment is a process to control assets and family resources, ownership of assets, an excuse for employment, and access to markets and representation in economic decision-making roles. With economic empowerment, women can attain financial independence, subscribe to the workforce, and have equal opportunities to gain positions of economic power (UN Women, 2018).

\section{Social and Cultural Empowerment}

Socio-cultural factors are enormously established elements of a particular society and circumscribe the values, attitudes, norms, practices, institutions, stratifications, and associated ways of an organization (Khan \& Mazhar, 2019). Social and cultural empowerment consists of truancy of discrimination against females, authority over their bodies, and freedom from sexual and domestic violence, having access to family planning services, larger distinctness in social reservations, and alterations in cultural norms that spot women docile to men (Chatterjee, n.d.)..

\section{Political Empowerment}

Political empowerment is a process concerning the prudence of producers to seek claims on such actors and institutions and hold them answerable. Political empowerment is the dimension of smallholders to have an opinion and to exercise control in the organizations, profess to represent them or speak on their behalf, such organizations be producer corporations, NGOs, or the growing assemblage of private and multi-stakeholder standard-setting initiatives, associated with fair and ethical trade and CSR (Utting, 2012).

\section{The Correlates of the Dimensions of Women Em- powerment}

The salient dimensions of women's empowerment include self-esteem, mobility, control of resources, and decision-making. Intimate to these dimensions, there are the demographic, economic, and social status of women and women's exposure to media, termed the determinants of women's empowerment. Jejeebhoy, (2000) draws a correspondence between the dimensions and the determinants as in Fig 1 below.

\section{Globalization : Concept}

The word globalization is multi-dimensional with economic, social, cultural, and political implications. Torres, (2001) designates globalization as a method of swift economic integration among countries propelled by trade liberalization, investment, and capital flows, as well as technological change. Globalization has limited the dissimilarities among different countries and its nation..

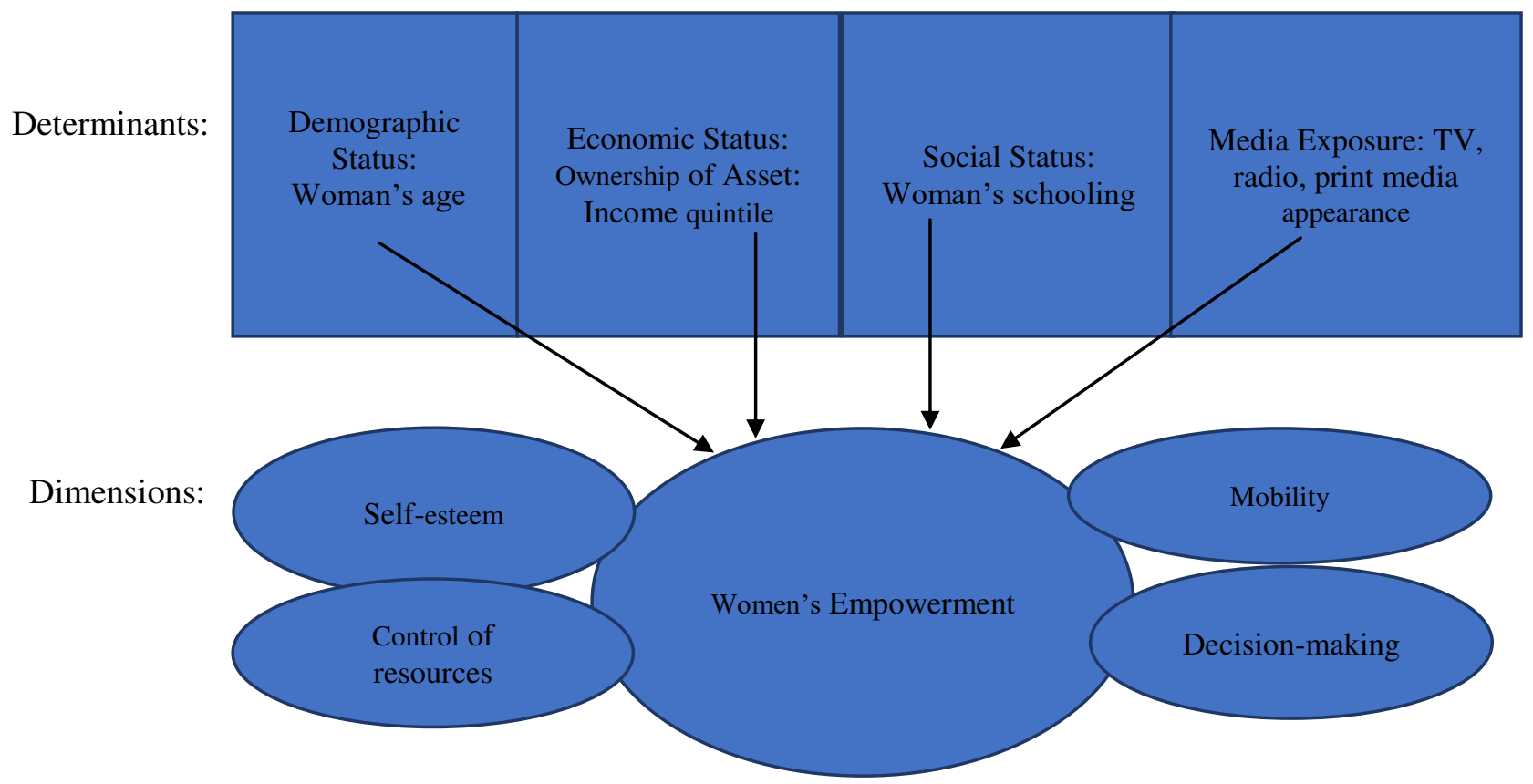

Fig 1: Determinants and Dimensions of Women's Empowerment (Source: Adopted from Jejeebhoy in Presser and Sen, 2000). 
Considering the early $16^{\text {th }}$ century, national and regional economies throughout the world have been uniting, and in the twentieth century, some pointers of globalization were very powerful. Newly globalization has performed brilliant momentum in its description and depth. The effectiveness of globalization is the assumption of nationwide economy, hitech modification, and process of production, distribution of sources, institutional changes, and formulation of policies of the different countries of the world. Globalization has tremendous influences on both genders and also on their families. The most observed effect of globalization is the heightened participation of females in the paid labor market more than males (Standing, 1999). Global manners change gender relations and roles and reinforce gender inequalities, but embedded in a gendered reality and gendered philosophies. In different third world countries, men are driving to urban centers in quest of better-paid work; due to their absence, women have subscribed to the agricultural labor force. Under this circumstance, women usually become household heads and primary wage earners

Globalization refers to the outcome of transferring "mediascapes, technoscapes, ethnoscapes, finance scapes, and ideoscapes" (Appadurai, 1996). Cultural homogenization and cultural heterogenization are the advanced problems of today's global interconnection (Appadurai, 1990). The author discusses how the five necessary assembles abolish the unfounded conceptions of distinct economies and "pure capitalism." These five dimensions of global cultural flow cause a "disordered capitalism." And confused capitalism requires the separate, disjointed operations of the "economy, culture, and politics." Joseph Stiglitz, (2002) designated globalization as the adjacent integration of countries, brought about by the tremendous reduction of costs of transformation and communication, and the collapsing of fabricated barriers to the movements of goods, services, capital, knowledge, ideas, and to a minor extent, people beyond borders. A recent publiccation of the World Bank (World Bank, 2002) identified the three waves of globalization. From 1870 up to 1914, has been identified the first wave of globalization and between 1950 and 1980 witnessed the second wave. And, the third or the latest wave of globalization started in the 1980 s, which proceeds to date.

\section{Dimensions of globalization}

Globalization is a multifaceted concept. The broad dimensions of globalization are Economic globalization, Socio-cultural globalization, and Political Globalization. These dimensions are oversimplified, and they often obscure interconnections and overlaps between compasses of globalization (Mascia-Lees, 2010).

Economic globalization: Economic globalization is a process regarding the integration of individual countries' organizations of production, distribution, and consumption of commodities into the world economy (Chase- Dunn, 2000). International trade in goods and services, foreign direct investment, and global financial flows are the three most prime vehicles of economic globalization (Mahler, 2004).

Socio-cultural globalization: Socio-cultural globalization is a process of communicating ideas, significations, and principles surrounding the world to expand social relations. It connects to the illustrative structure, articulation, and dissemination of application.

Political globalization: Political globalization consists of the national governments, related to their governmental and inter-governmental organizations and the government sovereignty components of global civil society such as international non-governmental organizations and social mobility organizations. One of the exceptional examples of political globalization is the cosmos and the continuation of the United Nations.

\section{The Globalization-Women Empowerment Nexus}

Women's empowerment is a position to secure that woman can fully possess equal rights as men and are not discriminated against, which is sensibly acceptable. It is also instrumentally estimable because it fosters economic development (Sen, 1999). Comprehensive atheists of globalization suggest the masculinity of corporate globalization commencing to the subjugation of women across the world (Chafetz, 1984; Enloe, 2007; Klein, 2007; Shiva, 2005; Ward, 1984). (Wichterich, 2000) demonstrated that a globalized woman burned up as a natural fuel; she is the sweatshop worker in export industries and the voluntary worker who helps assimilate the collapses of social reduction 
and structural adjustment. (Baneria, 2003) confirms that globalization is a process of global market enlargement that connects to the market has historically been different for men and women with moments for their decisions, choices, and behavior. The author highly points out the feminist economic literature that confesses impulses other than self-interest in judgments and behaviors of people, including self-sacrifice, considering, and integrity. These are highly associated with women. Katz, (2001) represents a pure topography of globalization, which necessitates a channel for developing a gendered oppositional politics that drive across scale and space. Gibson Graham, (2006) affords an alternative pageant of capitalism and socialist politics. Feminists defied not a patriarchal authority but a world in which the division of vast areas of practice into the superior male and less sufficient female domains was a matter of general sense, admitted as self-evident by most men and many women. Haussmann and Sauer, (2007) contrast the impact of women's policy agencies and the women's campaign on current pivotal environment policies in fourteen countries from the 1990s to today. The authors used the Research Network on Gender and the State (RNGS) model of women's movement and policy actor artifices to impact public policy deliberations and state rejoinder. Most of the investigation on the impact of trade liberalization converges on women in wage employment evaluates how their job and benefits are affected through an increase (or decrease) in exports and imports. Standard trade theory declares that comparative advantages of a country in trade based on its part revenues (labor or capital) and consign those commodities that use its approximately plentiful portion most intensively. The Heckscher-Ohlin-Stolper-Samuelson (HOSS) theorems prognosticate those reactions to the relatively abundant factor used in exports will stimulate the demand for increases (Heckscher and Ohlin, 1991; Stolper and Samuelson, 1941). As developing countries are over-flowing in labor rather than capital, the liberalized trade expected double the labor (wages). Heterodox theorists support that trade, based on a positive or competitive advantage (Adam Smith, 1776) rather than comparative advantage. That means a country that provides goods more cheaply will control the inter-national market and exceed its competitors. Women are thus suitable as a UniversePG I www.universepg.com cause of competitive advantage for export-oriented industries that face intense com-petition in the global business, and the desire for their labor emanates. The contrast between competitive advantage and comparative advantage is a country can design a labor-intensive good more efficiently than a capital-intensive good. The export industry could not consign and even have its industry crash through trade if its trading partners produce both goods more economically. Black and Brainerd (2004) affirm that globalization is a method that leads to forwarding pressures that will decrease the expanse for employers to distinguish, including discriminating against women. Female workers in this framework are assumed to be identically skilled/ productive as male workers. As per the heterodox theory, a dog-eat-dog economy accepted continuous discrimination (Darity, 1989; Darity and Williams, 1985). In this approach, the relative bargaining power of workers determines wages, determined by worker skills and job characteristics. Kroliczek, (2016) recommended circumscribing the relationship between globalization types and their ability to support gender equality. The author used the KOF Globalization Index and the Global Gender Gap Index (GGG Index) to examine the relationship between three dimensions (sub-indexes) of the KOF Index (economic globalization, social globalization, and political globalization) and gender equality. The author also used the SIGI Index 2012 (OECD) to estimate the meaningful or irrelevant relationship between socio-cultural globalization (KOF Index) and the outcome achieved under social globalization type on gendered social contracts (SIGI Index). Empirical studies of the impact of globalization on women also conduct out inconsistent findings (Horgan, 2001). Although globalization cuts women, it has also produced a substantial opportunity for women. Women are responsible for the first time to be financially independent of men and to have at least some security in their personal lives. Essentially, by creating opportunities for women into the workforce, globalization has given women the power to end the system that spawns poverty, exploitation, and oppression. Butale, (1997) tended out that over the past two decades, the process of globalization has committed to widening inequality within and among countries, combined with the economic and social fall down in parts of Sub-Saharan Africa and countries in trans- 
formation like in Eastern Europe. Women are getting utilized by Transnational Corporations with the conspiracy of their governments which reflects economic inequalities. Foreign direct investment, export/GDP ratio, and trade openness determine the consequences of economic globalization on women's economic empowerment in Bangladesh. Rahman, (2014) designnates the association between the gender gap and trade liberalization in Bangladesh with a pivotal significance on the ready-made garments for consolidating the highest number of female workers, has 77.12 percent portion in overall trading results and has a 14 percent share in GDP. The research observed that free trade increased female participation in the export sector by five times, but the discrimination against females is still high in the work environment. Conversely, the income gap between females and males is feeble due to the longer work relays of males, female workers requiring skills and education, skepticism, and ill manner of employees towards inclinations of females. The overall impact on women's welfare is a controversial issue (Khundker, 2002). The author assumes the Bangladesh dimension of the interface of globalization and women. The researcher used several social and economic variables to look at the impact of globalization on women in Bangladesh through a preand post-analysis. (Barkat and Maksud, 2001) pointed out that women's contribution to family, society, and national development, is a struggle to recognize and parse the factors associated with the possible impact of globalization on Bangladeshi women. Globalization inaugurates new opportunities worldwide. It designs lifestyles, consumption patterns, consumerist values, communication patterns, styles of urbanization, and cultural customs. Jahan, (2014) studied the impact of globalization on women in Bangladesh from economic, social, and cultural viewpoints. The author shows that how a woman is affected by globalization depends on converging factors such as class, race, ability, age, and education. For example, the upperclass women in Bangladesh have significantly profited through better education, new technologies, better employment, and increased purchasing power. The revolt of NGOs commenced the global centralization and financial liberalization as micro funders (Karim, 2011). The authority of the market and removal of the state transformed economic structures, with the ultiUniversePG I www.universepg.com mate result that development funding constructs through institutional financial investors. Microcredit itself converted into a formal discussion as the means for individual entrepreneurs to break out of poverty. The interconnection between NGOs and certified investors concentrates on women's manifest empowerment and throws back a neoliberal interpretation. The adjustment of the planning conversation of globalism into a developmental matter has made the natural process of development an on-the-move activity, a social program, and a war on poverty administered on a global scale through microfinance. Bacchus, (2005) discusses the insufficiency of emergency tariffs that allow corporations to take advantage of female workers. Women also go through to work in dangerous conditions that can cause health problems alongside low wages. The effects of globalization and free trade on women in Bangladesh have made the audience understand the film The Hidden Face of Globalization, (2003). Young women workers who work long, tedious hours to support their families face several health problems and dissipate productivity. Sometimes the workers who work in textile industries are disclosed to dust, and fluff can cause lung disease.

\section{Women Empowerment In Bangladesh: Generic Observations}

This section implements generic observation about women's empowerment in Bangladesh as evidenced by the developments in various indicators about women's participation and supplement associated with men. Indicators incorporate political, social, economic, and cultural dimensions of women's empowerment as well as women's holding decision-making areas. Under the Two-Year (1978-1980) Plan organized the first program and same as in the 3rd 5 Year Plan (1985-90), expanding the employment and occupation of the women.

\section{The Bangladesh Government Initiatives for Women Empowerment}

Bangladesh has been attempting several policies and programs to mitigate the position of women in society. To accomplish the policy; and engage the commitments of the Beijing Platform for Action, a National Action Plan had approved in 1998. Women's Development policy had corrected in 2004, and 2008 respectively. The present government has expressed the 
National Women Development Policy 2011to execute electoral promises and secure women's development and empowerment.

\section{National Women Development Policy 2011 for Wo- men Empowerment in Bangladesh}

Women empowerment is a progressive concept. Development is related to socio-economic concerns as gender equality and women's empowerment, recognized by specialists. Subsequently, the government has adopted and sanctioned women's development policies at different times to practice gender equality and women empowerment and accomplished remarkable progress with a short time. Achievement of the National Women Development Policy 2011 is the triumphant result of the Bangladesh government in women's well-being. The progress executed in terms of the policy as well as consequences can point out as follows:

\section{Gender-Responsive Budgets}

The Government of Bangladesh expressed a genderresponsive budget for securing the participation of women in various programs since 2009. Allocation for women's development is Tk. 7,908.7 million that is 26.80 percent of the total budget in fiscal year (20182019).

\section{Ensuring Political Participation of Women}

In Bangladesh, women's progress in the political platform is meaningful as women maintain the top positions in political leadership. At the highest decisionmaking level, a conspicuous number of women ministers in the cabinet are like the Honorable Prime Minister of the state. In the $10^{\text {th }}$ National Election, 48 women were instantly elected as members of parliament that added to the reserved, constituted $28 \%$ of the total seats.

\section{Ensuring Administrative Empowerment of Women}

The number of women who work as among the Justices of the Supreme Court, top positions of the administration - secretaries, additional secretaries, joint secretaries, deputy commissioners, and the top places of police, defense forces, and UN pacifier-specifies the development in women's empowerment.

\section{Ensuring Economic Participation of Women}

There is an expanding trend of increased women's participation in the labor force. Bangladesh enhanced its women's labor force from $24 \%$ in 2010 to $36 \%$ in 2013. A micro-level study transferred in 2008 reveals that $88 \%$ of women are getting occupied in agriculturerelated works $(\mathrm{GoB}$, Ministry of Women and Children Affairs, 2011. Four million women get manipulated in the garment sector (GoB, Ministry of Labor and Manpower, 2010).

\section{Skill Training for Women Development}

Continuing projects and programs designed for women entrepreneurs training on different trades. A fund organized by the revenue budget for the social, economic, and political empowerment of women.

\section{Education of Women}

The performance of gender priority is successful in primary education. Primary school enrollment had progressed 1.4 times from 11.9 million in 1990 to 16.7 in 2008 since 1990. Secondary education enrollment for female students had increased significantly as girls (52\%) had transcended boys (48\%) in 2000. Primary and secondary education is free of cost for girls. Government provisioned stipends and waivers of tuition fees to increase primary and secondary enrollment for girls.

\section{Health of Women}

Bangladesh achieved audible progress in the area of women's health. The government executed several actions to deliver primary health care services to rural poor women in community clinics. Besides, the government paid more attention to expediting maternal healthcare resulting in a diminished maternal mortality rate. The Bangladesh government established ten women-friendly Model District Hospitals and Upazilla (sub-district) Health Complexes to treat women and children.

\section{Poverty Alleviation and Social Security of Women} The VGD (Vulnerable Group Development) is one of the most consequential social safety net programs of the Bangladesh Government. The government distributed $30 \mathrm{~kg}$ of rice each month among ten Lac poor women to surmount prevailing food insecurity, malnourishment, financial insecurity, and social degradation under the sunshade of VGD.

\section{Social Empowerment of Women}

Social security strengthens the social empowerment of women. Formal and informal education and practical 
activities enhanced women's confidence, knowledge, learning, creativity, and change management content. Changing social norms and practices and ensuring women's social empowerment promotes women's alliance for voice, agency, and passage to justice.

\section{Legal Empowerment of Women}

To restrict certain forms of violence against women, Bangladesh has several specific laws such as the Penal code 1960A; Anti-Dowry Act 1980; A Prevention of Repression Against Women and Children Act -2000 (revised in 2003), Acid Crime Control Act, etc. Albeit extraordinary constitutional services and legal laws have guaranteed women's equal rights, due to some prejudicial personal laws, political history, patriarchal socio-economic system, Bangladesh could not proceed to the expected direction and emulate to realize gender equality (Aminuzzaman, 2018). The Women Development Implementation and Monitoring Committee (WDIMC) sometimes judged the progress to execute the National Action Plan for Women Advancement (NAP), but official journalism did not work.

\section{Limitations of the Policy}

1) The policy did not amend for a long time;

2) The policy cannot prevent abuse against women;

3) The budget of this policy is finite;

4) The penal codes law did not impose appropriately;

5) Discrimination against women did not stop yet;

6) There is no official system of making a followup of the noticeable policy.

\section{Recommendation for the policy}

1) The law should impose strictly;

2) A positive domain for women in politics should create;

3) Provisions for women entrepreneurship should provide;

4) The budget regarding women's development should increase, and the allocation should be fair.

The government should lessen the disparity in the education system. An effective education policy should adopt. Aminuzzaman, (2018) considered that Bangladesh is an applicant to many international conventions and etiquettes to eliminate women's rights and therefore is devoted to reinforcing such values and provisions. CEDAW (Convention on the Elimination UniversePG I www.universepg.com of all Forms of Discrimination against Women) (1984), Implementation of the Beijing Platform for Action (PFA) (1995), ILO (International Labor Organization) Convention $(1935,1948,1951,1958)$, UN Convention, $(1953,1966,1979)$, and The SAARC Dhaka Declaration (2005), etc. are some of the conventions. The consequence of empowering women is to take part equally in all settlements to employ them and assure their participation at decision-making levels. To secure the proper implementation of the pronounced public policies, the government of Bangladesh should immediately acquire a Policy Implementation Tracking mechanism.

\section{METHODOLOGY:}

To illustrate the impact of globalization on women's empowerment in Bangladesh, we first demonstrate a qualitative analysis. Globalization has a diverse effect on the lives of women in developing nations (Markovic, 2007). Globalization presents women with a sharp future (Momsen, 2004). New technology and the internet have boosted globalization, and it would help enhance skill development for women. Globalization spreads confidence and power to earn more money to strengthen their families. In Bangladesh, the advantages of globalization contribute to women are political, social than economic. With global interaction, women can consider everything to handle domestic violence and how to commence small businesses. The mixed effects of globalization in Bangladesh are as follows:

1. Economically, globalization has heightened employment opportunities for women but admitted differentiation in favor of male workers, persecution of women in unpaid or informal labor, ill-treatment of women in low-wage piece-rate workers, and poverty through the usual sources of income.

2. Politically, women's social integration through the globalization process has managed to the potential for new forms of participation and empowerment. Women's greater participation in political and social development has bettered their awareness and permitted those to feel honored as development activists. At the same time, women are also concerned about expulsion from the domestic political process and loss of control to global constraints. 
3. Socio-culturally, globalization is reconstructing the familiar organizational structures of society, although there is shorter agreement on what these changes entail. The extreme absorption of the mass media, the film industry, and publishing into the hands of a few corporations and individuals is leading to homogenous global mass culture. Globalization influences different groups of women in separate ways to create new properties for the execution of women and supports women's groups congregate. Women are used the wrong way in international marketing of sex trafficking, tourist enjoyment, and other unethical exercises. Interpreting the effect of globalization on women's empowerment in Bangladesh, this study uses a quantitative approach by investigating the correlation between selected indices of women empowerment and selected indices of globalization.

\section{Choice of Globalization and Women Empowerment Indices}

For two reasons, the study chooses the KOF index from among the various globalization indexes to represent globalization. First, the KOF index is a comprehensive measure of the rate of globalization. The KOF index has three dimensions of indicators: economic, social, and political. The KOF index of globalization evaluates the current financial flows, constraints, and data on information flows, data on personal contact, and data on cultural proximity. Secondly, the KOF index data for Bangladesh has been available consistently since 2007, while data on other globali- zation indices are rarely convenient. The Global Gender Gap Index apprehended women's empowerment. This index is intended to capture women's disadvantage associated with men and is not just a measure of equality of the gender gap. The GGG index has four sub-indexes (economic participation and opportunity, educational attainment, health and survival, and political empowerment). To measure the correlation between globalization and gender equality, it is the only way by the KOF index and the GGG index. The SIGI index is the best index to measure social contracts, which is also compatible with the methodology of the KOF index. We, therefore, use both the GGG index and the SIGI index for empirical analysis. The GGG Index estimates the scale from 0-1 (inequality-equality), while the KOF Index gives an estimate of the scale from 0 -100 (least globalized-most globalized). SIGI Index measures 0 for social contracts positive support for gender equality and 1 for negative support for gender equality. In Bangladesh, data are ready for the GGG index (2006-2017) but the SIGI index only (2009, 2012, and 2014). The Global Gender Gap Index aims to identify progress on relative gaps between women and men in health, education, economy, and politics in the world, over the past 11 years. From 2006 to 2017, progress is apparent for Bangladesh, and it is the chief among the South Asian countries. Table 1 and Fig 2 represent the score of Bangladesh for the period of 2006 to 2017.

Table 1: Score of Bangladesh in GGG Index from 2006 to 2017 (Source: Global Gender Gap Index 2006-2017).

\begin{tabular}{|c|c|c|c|c|c|c|c|c|}
\hline \multirow{2}{*}{ Year } & \multicolumn{2}{|c|}{$\begin{array}{c}\text { Economic Participation and } \\
\text { Opportunity }\end{array}$} & \multicolumn{2}{c|}{$\begin{array}{c}\text { Educational } \\
\text { Attainment }\end{array}$} & \multicolumn{2}{c|}{ Health Survival } & \multicolumn{2}{c|}{$\begin{array}{c}\text { Political } \\
\text { Empowerment }\end{array}$} \\
\cline { 2 - 9 } & Rank & Score & Rank & Score & Rank & Score & Rank & Score \\
\hline 2006 & 107 & 0.423 & 95 & 0.868 & 113 & 0.950 & 17 & 0.267 \\
\hline 2007 & 116 & 0.437 & 105 & 0.871 & 122 & 0.950 & 17 & 0.267 \\
\hline 2008 & 119 & 0.444 & 104 & 0.909 & 124 & 0.950 & 13 & 0.310 \\
\hline 2009 & 121 & 0.455 & 105 & 0.911 & 127 & 0.950 & 17 & 0.294 \\
\hline 2010 & 117 & 0.473 & 108 & 0.914 & 122 & 0.956 & 12 & 0.338 \\
\hline 2011 & 118 & 0.493 & 108 & 0.917 & 123 & 0.956 & 11 & 0.359 \\
\hline 2012 & 121 & 0.480 & 118 & 0.858 & 123 & 0.956 & 8 & 0.380 \\
\hline 2013 & 121 & 0.495 & 115 & 0.884 & 124 & 0.955 & 7 & 0.403 \\
\hline 2014 & 127 & 0.4774 & 111 & 0.9402 & 122 & 0.9663 & 10 & 0.4055 \\
\hline 2015 & 130 & 0.462 & 109 & 0.948 & 95 & 0.971 & 8 & 0.433 \\
\hline 2016 & 135 & 0.410 & 114 & 0.950 & 93 & 0.971 & 7 & 0.462 \\
\hline 2017 & 129 & 0.465 & 111 & 0.954 & 125 & 0.966 & 7 & 0.495 \\
\hline
\end{tabular}




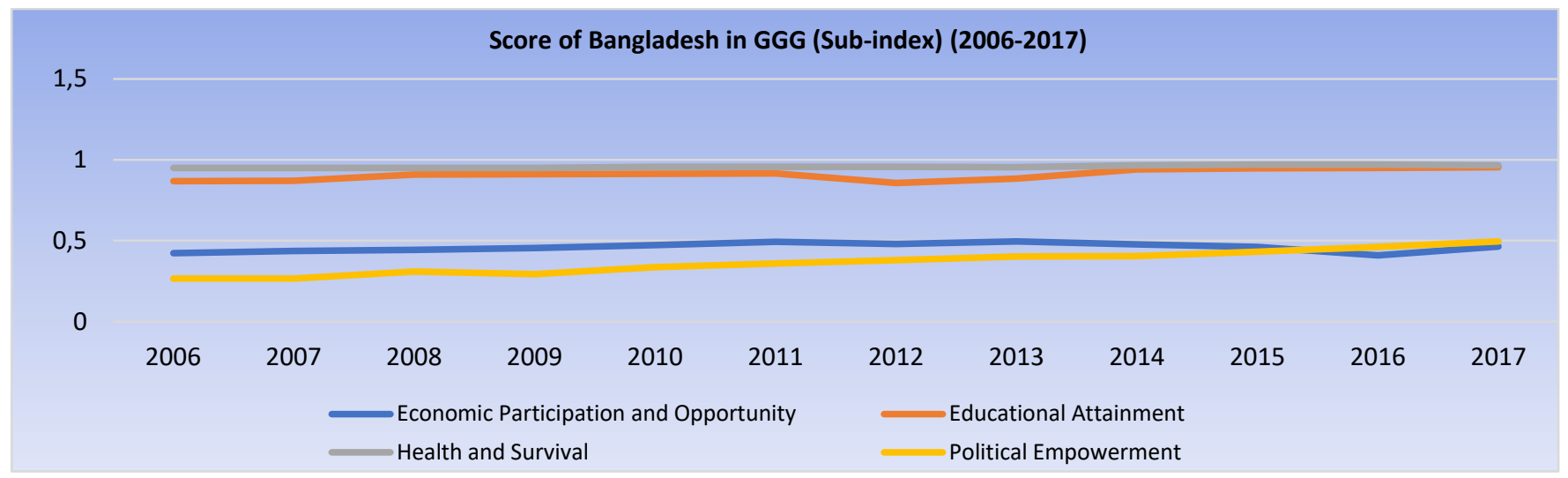

Fig 2: Score of Bangladesh in GGG (Sub-index) (2006-2017).

From the GGG report of Bangladesh, we can say that political empowerment heightens through enlarged membership in the national parliament. But in terms of economic empowerment, improvement is ongoing in expanding the labor force participation of women. With the rate of progress in the education sector, more and more women are sub-scribing to the labor force, although there is still a long mile to go. In Social empowerment, laws are adequate but, the execution is limited. Effective implementation of CEDAW and other gender-related laws to restrict social violence and discrimination against females in social and economic compasses remains the main provocation.

Table 2: Ranking of Bangladesh in KOF Index and GGG Index (2017) (Source: Author prepared the Table using KOF Index and GGG Index data).

\begin{tabular}{|c|c|c|c|}
\hline Sub Index & KOF Index & Sub Index & GGG Index \\
\hline Economic Globalization & 153 & Economic Participation and Opportunity & 129 \\
\hline Social Globalization & 187 & Educational Attainment & 111 \\
\hline Political Globalization & 70 & Health and Survival & 125 \\
\hline & & Political Empowerment & 7 \\
\hline
\end{tabular}

As shown in Table 2, Bangladesh has a long way to go to be globalized (KOF Index). Bangladesh is moving forward by political globalization but still in a lower position in economic and social circumstances. It is necessary to increase the development sector to enrich its status in the world economy as Bangladesh can compete with the highly globalized countries. To sustain its position in the global economy, women's participation in Bangladesh should increase in all compasses of the development sector (economic, social, and political). In GGG Index, Bangladesh is doing a premium rank in political empowerment but procrastinates in others. Table 3 and Fig 3 represent the clear picture of the score of Bangladesh in KOF Index for the period of (2007-2017).

Table 3: Score of Bangladesh in KOF Index (2007-2017) (Source: KOF Index 2007-2017).

\begin{tabular}{|c|c|c|c|}
\hline Year & Economic Globalization & Social Globalization & Political Globalization \\
\hline 2007 & 29.52 & 18.63 & 70.59 \\
\hline 2008 & 31.57 & 17.51 & 74.79 \\
\hline 2009 & 32.48 & 19.88 & 75.07 \\
\hline 2010 & 36.48 & 19.95 & 75.94 \\
\hline 2011 & 33.34 & 19.79 & 78.27 \\
\hline 2012 & 34.49 & 21.05 & 77.42 \\
\hline 2013 & 34.47 & 20.99 & 77.16 \\
\hline 2014 & 33.84 & 24.42 & 77.46 \\
\hline 2015 & 35.28 & 24.21 & 76.68 \\
\hline 2016 & 35.82 & 23.92 & 75.89 \\
\hline 2017 & 33.62 & 21.56 & \\
\hline
\end{tabular}




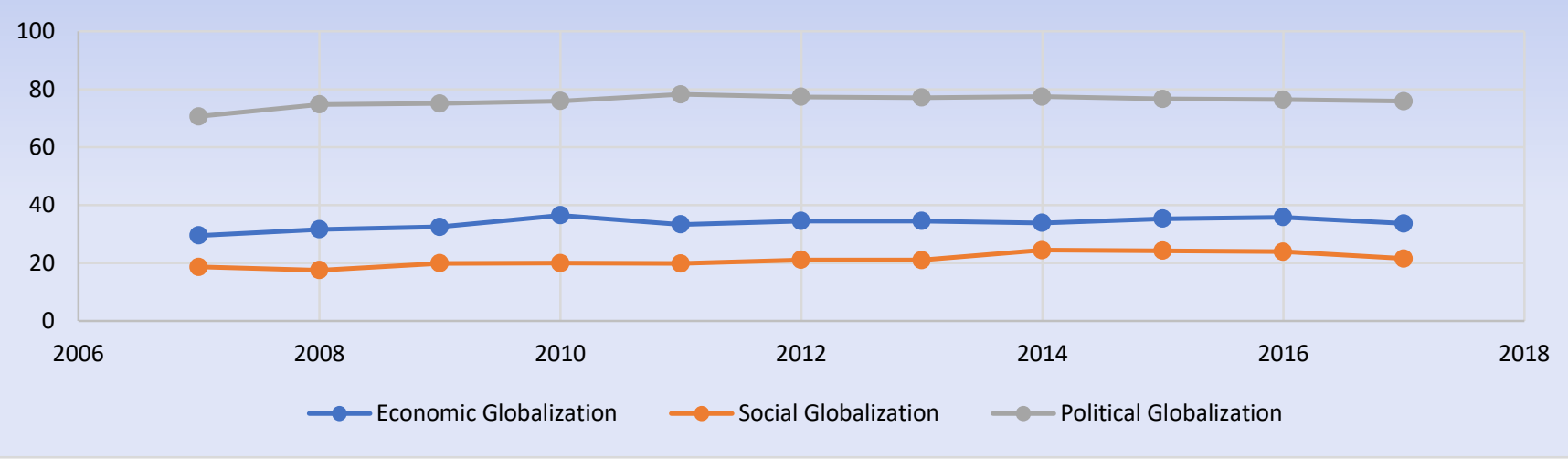

Fig 3: Score of Bangladesh in KOF Index (2007-2017).

The Correlations between KOF index and GGG index

The KOF index is a comprehensive measure of globalization while the GGG index is a comprehensive measure of women empowerment. Fig 4 shows the scatter plot of the two indices for the period 2007 to 2017. The graph shows that there is a positive relationship between the two indices. Indeed, the estimated regression equation shows that an increase in the KOF index by one percentage point leads to a 0.01 percentage point increase in the GGG index and vice versa. The estimated correlation coefficient between the indices is 0.86 , which suggests that the two indices are highly positively correlated. The KOF economic globalization sub-index is positively correlated with the GGG economic participation sub-index as shown in Fig 5.

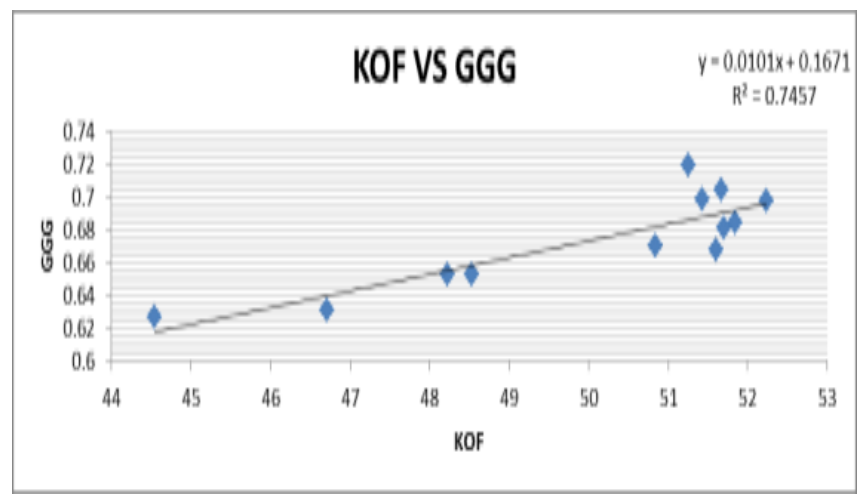

Fig 4: Scatter Plot of KOF Overall Index and GGG

Overall Index (2007-2017).

The estimated correlation between the two indices is 0.55. The estimated regression coefficient indicates that an increase in the KOF sub-index by one percentage point leads to an approximately 0.01 perUniversePG I www.universepg.com centage point increase in the GGG sub-index and vice versa.

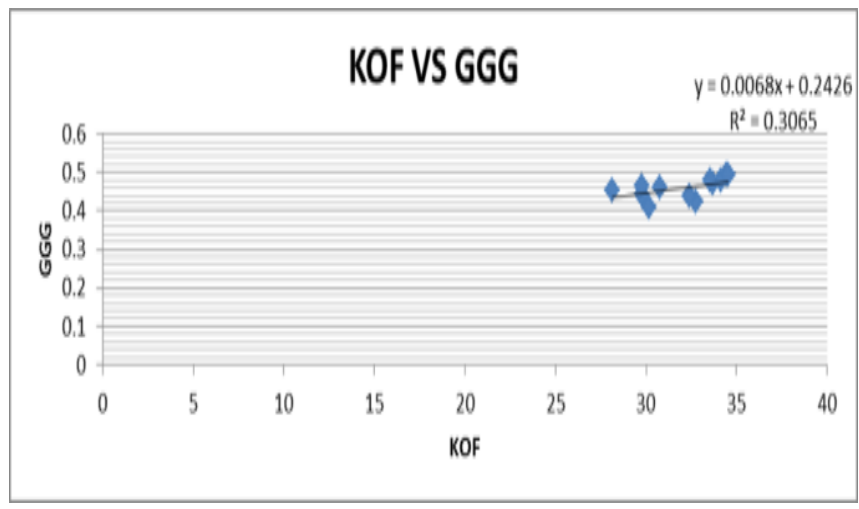

Fig 5: Scatter Plot of KOF Economic Globalization Sub-Index and GGG Economic Participation and opportunity Sub-Index (2007-2017).

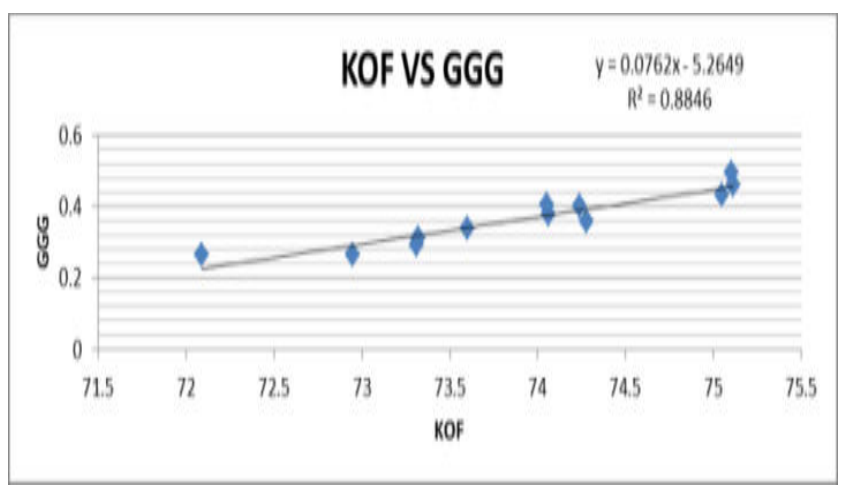

Fig 6: Scatter Plot of KOF Political Globalization SubIndex and GGG Political Empowerment Sub-Index (2007-2017).

The KOF political globalization sub-index and the GGG political empowerment sub-index are highly positively correlated, the correlation coefficient is 0.94 . The regression coefficient suggests that a one per- 
centage point increase in the former leads to about 0.08 percentage point rise in the latter and vice versa. The two sub-indices are plotted in Fig 6. As shown in Fig 7, the scatter plot of the KOF social globalization subindex and the SIGI empowerment index show that the two indices are highly positively correlated. The correlation coefficient is 0.96 . The regression co-efficient suggests that a one percentage point increase in the KOF index leads to a 0.03 percentage point increase in the SIGI index and vice versa.

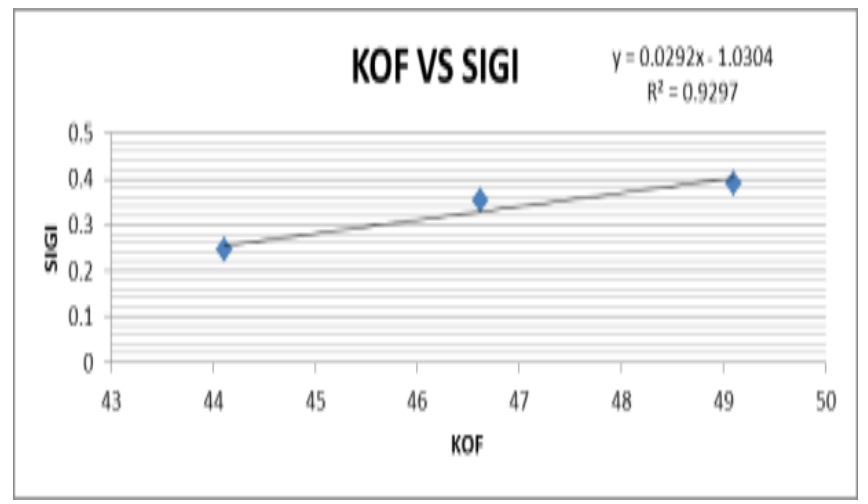

Fig7: Scatter Plot of KOF Social Globalization SubIndex and SIGI Index (selected years).

From the economic outlook, globalization introduces the breakthrough from which everyone advantages. Employment collects in market appliances encourage competition among countries following in a better quality of goods and services prepared for the customer. But as a developing country like Bangladesh is not in a place to secure the interests of the system due to the country's backwardness and colonial past while the country is becoming the market of goods produced by most developed countries. Data shows that women are accumulating receipts from raising barriers to markets and societies through improved technological skills and therefore shape their lives toward advancement in their occupations. Bangladesh has a positive correlation between the KOF economic globalization vs. GGG economic participation and opportunity with 0.55 (Scatterplot 2). So, Bangladesh has to pay more attention to strengthening women's labor force participation and has to generate more opportunities for women. Bangladesh has the highest correlation recognized on the KOF social globalization vs. the SIGI Index with 0.96 (Scatterplot 4). Women guide to create several little reliabilities -especially in the social realm, but also in the management of daily life and mainUniversePG I www.universepg.com tenance, in ecology, culture, politics, and civil society in a condition where the general sense of security is misplaced. In Bangladesh, old family bonds are destroying, and nuclear families are progressing. The state and capital are leaving engagements and contests, male brutality, and social stresses are heightening. Traditionally the political process, authority, and leadership have been highly controlled by males. But Bangladesh is exceptional with the highest decision-making level where women as some ministries in the cabinet and the Honorable Prime Minister are women of the state. In Bangladesh, the impact of political globalization on women's empowerment is amazingly high (Scatterplot 3) that indicates the installed great international organization's correlative albeit the international organizations and embassies work have to work on the politic-unbiased ground and direct control on the female contestants.

\section{CONCLUSION:}

To conclude, globalization has a diverse impact on the entities of women in Bangladesh. From a positive perspective, it strengthens the participation of women in the labor market, women's independent migration to metropolitan areas, and greater visibility of women in public spaces. These changes have, to some extent, helped break the job market segmentation and a narrowing of the wage differentials over time amid men and women. The present challenge is to develop on these positive steps, ensuring that women can effectively participate in an extensive range of economic and social areas on equal terms with men. From the negative aspect, women of Bangladesh operate as sweatshop workers in trading industries. The workers who live abroad and refuse foreign currency, sensuality workers or description brides, spousal markets, and the spontaneous worker who help fight the excitement of social modification inducted by the structural adjustment. The fundamental essential is to understand under such terms and the variables required determining the effects of globalization on women's stage of life, identity, and state. To diminish the negative impacts on women, need social change, experienced and respecttively agreed on action programs among business schools, corporations, and other powers groups like the public sector and crushing the glass ceiling in MNCs, including codes of treatment as a part of their CSR 
(Corporate Social Responsibility). Besides, for participation in economic and political pursuit's broad level of social cooperation and government initiatives are necessary.

\section{ACKNOWLEDGEMENT:}

Professor Dr. Mohammad Abul Hussain, Department of Economics, University of Chittagong, Bangladesh, supported this study with proper supervision.

\section{CONFLICTS OF INTEREST:}

The author certifies that there are no conflicts of interest concerning the research work.

\section{REFERENCES:}

1) Afshar, H., and Stephanie B. (1991). Introduction: Women, Globalization, and Fragmentation in the Developing World. London: Macmillan. pp. 1-17. https://doi.org/10.1057/9780230371279_1

2) Aminuzzaman, Salahuddin, M. (2018). Study on Women Development and Empowerment: Policies and Issues.

https://www.researchgate.net/publication/3226552 $\underline{06}$

3) Appadurai, A. (1990). "Disjuncture and Difference in the Global Cultural Economy." Theory, Culture, Society, 7, 295-310.

4) Appadurai, A. (1996). Modernity at Large: Cultural Dimensions of Globalization. Minneapolis: University of Minnesota Press.

5) Bacchus, N. (2005). "The Effects of Globalization on Women in Developing Nat-ions". Honors College Theses. 2.

https://digitalcommons.pace.edu/honorscollege the $\underline{\mathrm{ses} / 2}$

6) Barkat, A., and Maksud, A.K. M. (2001). "Impact of Globalization on Women in Bangladesh: An Exploratory Study”. Human Development Research Centre: Bangladesh Nari Progoti Sangha.

7) Black, S. E. and Brainerd, E. (2004). Importing equality? The impact of globalization on gender discrimination. Industrial and Labor Relations Review, 57(4), 540-559. https://www.jstor.org/stable/4126682
8) Batliwala, S. (2007). "Taking the Power out of Empowerment: An Experiential Account." Development in Practice, 17 (4/5), 557-65.

9) Beneria, L. (2003). Gender, Development, and Globalization: Economics as If All People Mattered. Book, Whole. New York: Routledge.

10) Butale, C. (1997). "Globalization and its impact on Women in Developing Countries." Workingpaper.

11) Boserup, E. (1970). Women's Role in Economic Development, New York, St. Martin's Press.

12) Chafetz, J. S. (1984). Sex and advantage - A comparative, macro-structural theory of sex stratification. New Jersey: Rowman \& Allanheld.

13) Chaity, Afrose, J. (2018). Women Empowerment: Bangladesh sets an example for the world. The Dhaka Tribune, July 12, 2018. https://archive.dhakatribune.com/opinion/special/2 018/07/12/women-empowerment-bangladesh-setsexample-for-the-world

14) Chase-Dunn, C., Y. Kawano, and B.D. B. (2000). Trade Globalization since 1975: Waves of Integration in the World-System. American Sociological Review, 65(77), 9589. http://www.jstor.org/stable/2657290

15) Chatterjee, Irani, B. (n.d.). Woman Empowerment: Issues, Measurements, and Challenges. https://www.academia.edu/38569431/WOMAN_EM POWERMENT_ISSUES_MEASUREMENTS_AND_CH ALLENGES

16) Chen, M. (1992). Conceptual Model for Women's Empowerment. Unpublished.

17) Chowdhury, N. (1994). 'Women's Participation in Politics: Marginalization and Related Issues'. In Najma Chowdhury, Hamida Akhter Begum, Mahmuda Islam and Nazmunnessa Mahtab (Eds), Women and Politics (pp. 15-34). Dhaka: Women for Women.

18) Darity, W., \& Williams, R. (1985). Peddlers Forever? Culture, Competition, and Discrimination. The American Economic Review, 75(2), 256-261.

19) Darity, W. (1989). What's Left of the Economic Theory of Discrimination? In: Shulman, S. and Darity W., eds. Question of Discrimination: Racial Inequality in the U.S. Labor Market. Wesleyan University Press, Middletown. 
20) Enloe, C. H. (2007). Globalization and militarism: Feminists make the link. Lanham, MD: Rowman and Littlefield.

21) Freire, P. (1972). Pedagogy of the Oppressed. Montevideo, Editorial Tierra Nueva.

22) Global Gender Gap Index, (2006-2017). World Economic Forum (WEF).

http://reports.weforum.org/global-gender-gapreport-2006-17

23) Gibson-Graham, J. K. (2006). The End of Capitalism (As We Knew It). Minnesota: University of Minnesota Press.

https://www.upress.umn.edu/book-division/books/ the-end-of-capitalism-as-we-knew-it

24) Government of the People's Republic of Bangladesh, (2010). Labor Force Survey -2010. Dhaka; Ministry of Labor and Manpower.

25) Government of the People's Republic of Bangladesh, (2011). National Women Development Policy, 2011. Dhaka; Ministry of Women and Children Affairs.

26) Haider, R. and Akhtar, R. (1999). "The Role of NGO and Women's Perception of Employment: An Anthropological Study in a village." Empowerment: Women for Women, Dhaka, 6.

27) Haussman, Melissa, and Birgit, S. (2007). Gendering the State in the Age of Globalization: Women's Movements and State Feminism in Postindustrial Democracies. USA: Rowman \& Littlefield Publishers, Inc.

https://rowman.com/ISBN/9780742540163/Gender ing-the-State-in-the-Age-of-Globalization-Wome ns-Movements-and-State-Feminism-in-Postindust rial-Democracies

28) Heckscher, B. \& Ohlin, E. (1991). HeckscherOhlin Trade Theory. MIT Press, Cambridge MA.

29) Horgan, G. (2001). How Does Globalization Affect Women? International Socialism Journal, 2001(1), pp.1-10.

30) Hossain M.A., Tisdell C.A., and Ayon, T.H. (2012). Does Workforce Participation Empower Women? Micro-Level Evidence from Urban Bangladesh. Bangladesh Development Studies, 35(3).

31) Huq, M.S. (2016). Women Participation in Local Government: A Tool for Sustainable Develop- ment of Bangladesh. European J. of Business and Social Sciences, 4(11), pp. 169-183. http://www.ejbss.com/recent.aspx-/

32) Inglehart, Ronald and Pippa, N. (2003). Rising Tide: Gender Equality and Cultural change around the world: Cambridge, UK: Cambridge University Press. London: SAGE.

33) Islam, M. (2009). The Poverty Discourse and Participatory Action Research in Bangladesh. Research Initiatives, Bangladesh (RIB).

34) Jahan, M. (2014). "Globalization and Women in Bangladesh: A Review of Socio-Economic and Cultural Impacts" Journal of Culture, Society and Development, 4.

35) Jejeebhoy, S. J. (2000). "Women's Autonomy in Rural India: Its Dimensions, Determinants and the influence of the Context:" In Presser, H. B., Sen, G. (Eds.), Women's empowerment and demographic processes: Moving beyond Cairo (pp. 204-238). Oxford, UK: Clarendon Press.

36) Kabeer, N. (1995). Necessary, Sufficient, or Irrelevant? Women, Wages and Intra-household Power Relations in Urban Bangladesh. IDS Working Paper 25. Institute of Development Studies, Brighton.

37) Kabeer, N. (1999). Resources, agency, achievements: Reflections on the measurement of women's empowerment, Development and Change, 30,435-64.

https://www.researchgate.net/publication/2276124 $\underline{61}$

38) Karim, L. (2011). Micro-Finance and Its Discontents: Women in Debt in Bangladesh. Book, Whole. Minnesota: University of Minnesota Press.

39) Katz, C. (2001). "On the Grounds of Globalization: Topography for Feminist Political Engagement." Signs: Journal of Women in Culture and Society, 20(4), 1213-34.

40) Khan, M. \& Mazhar, S. (2017). Socio-Cultural Impediments and Women Empowerment. International J. for Innovative Research in Multidisciplinary Field, 3(7).

https://www.ijirmf.com/wp-content/uploads/2017 /07/201707069.pdf 
41) Khundaker, N. (2002). "Impact of Globalization on Gender the Bangladesh Perspective." The University Press, Dhaka.

42) Klein, N. (2007). The shock doctrine: The rise of disaster capitalism. London: Penguin Books.

43) KOF Globalization Index. Available at: http://globalization.kof.ethz.ch/10

44) Kroliczek, K. (2016). "Globalization and Gender Equality”. Central European University, Draft paper.

45) Mahler, V.A. (2004). Economic Globalization, Domestic Politics, and Income Inequality in the Developed Countries: A Cross-National Study. Comparative Political Studies, 37(9), 1025-1053.

46) Markovic, M., R. (2007). The Perspective of Women's Entrepreneurship in the Age of Globalization. Information Age Publishing, Inc. Charlotte, NC. www.infoagepub.com

47) Mascia-Lees, Frances E. (2010). "Gender, Difference, and Globalization." In Gender and Difference in a Globalizing World: Twenty-First Century Anthropol., 4-10. Waveland Press, Inc.

48) Momsen, J.H. (2004). Gender and Development. Routledge, London.

49) Parveen, S. (2008). Factors Affecting the Extent of Economic Empowerment of Women in Farm Households: Experiences from Rural Bangladesh. International Journal of Human Ecology, 117-126.

https://www.koreascience.or.kr/article/JAKO20080 $\underline{\text { 8349648116.pdf }}$

50) Rahman, M. M. (2014). "Trade Liberalization and Gender Gap: Bangladesh Experience," Journal of Applied Business and Economics, 16(2), pp. 57-69.

51) Rahman, Md. A. (2013). Women's Empowerment: Concept and Beyond. Global Journal of Human Social Science Sociology and Culture, 13(6).

https://globaljournals.org/GJHSS Volume13/2Womens-Empowerment-Concept.pdf

52) Sen, A. (1999). Development as Freedom. $O x$ ford: Oxford University Press.

53) Sen, G. (1997). Empowerment as an approach to poverty, Working Paper Series, background paper for the UNDP Human Development Report, New York: UNDP.
54) Sharma, S.L. (2000). "Empowerment without Antagonism: A case for Reformulation of Women's Empowerment Approach". Journal of Indian Sociological Society, 49(1), Delhi, India.

55) Shiva, V. (2005). The Polarized world of Globalization. Global Policy Forum.

http://www.globalpolicy.org/component/content/ar ticle/162/27674.html

56) Smith, A. (1776). "The Wealth of Nations" An Inquiry into the Nature and Causes of the Wealth of Nations, ed. Edwin A. Seligman (London: J. M. Dent, 1901), pp. 12-15,400-401,436-437.

57) Standing, G. (1999). Global feminization through flexible labor: A theme revisited. World Development, 17(3), 583-602.

58) Star Business Report (2018, Nov.18). More Women joining Labor Force: ILO. The Daily Star.

59) Stiglitz, E. J. (2002). Globalization and its discontents. Economic Notes, 32(1), 123-142. https://doi.org/10.1046/j.0391-5026.2003.001.x

60) Stolper, W. and Samuelson, P. (1941). Protection and Real Wages. Review of Economic Studies, 9(1), 58-73.

61) Sultana, F. (2014). Gender Equality and Women's Empowerment. Suggested Strategies for the $7^{\text {th }}$ Five-Year Plan. General Economics Division Planning Commission Government of Bangladesh.

62) The Hidden Face of Globalization (2003). AntiGlobalization, Wal-Mart, Women Workers and Child Labor. The United States. Agit-Prop Documentary. National Labor Committee (NLC).

63) Tolentino, J. (2016). "How 'Empowerment' Became Something for Women to Buy." The New York Times, April 12, Magazine.

https://www.nytimes.com/2016/04/17/magazine/ho w-empowerment-became-something-for-womento-buy.html

64) Torres, R. (2001). "Towards a Socially Sustainable World Economy: An Analysis of the Social Pillars of Globalization" Studies on the social dimensions of globalization, Geneva, International Labor Office.

65) UN Women, (2018). Facts and Figures: Economic Empowerment. 
https://www.unwomen.org/en/what-we-do/economic-empowerment/facts-and-figures

66) Utting, P. (2012). The Challenge of Political Empowerment. 24 Mar 2012

http://www.capacity.org/capacity/opencms/es/topic s/value-chains/the-challenge-of-political-empowerment.html

67) Ward, K. B. (1984). Women in the world system. New York: Praeger.
68) Wichterich, C. (2000). The globalized woman: Reports from a future of inequality. London: Zed Books.

69) World Bank, (2001). Engendering Development: Through Gender Equality in Rights, Resources and Voice. World Bank Policy Research Report. Oxford: Oxford University Press. https://documents1.worldbank.org/curated/en/5129 11468327401785/pdf/multi-page.pdf

70) World Bank, (2002). Globalization, Growth and Poverty, Oxford University Press, New York.

Citation: Dhar S. (2021). Globalization and its impact on women's empowerment in Bangladesh. Can. J. Bus. Inf. Stud., 3(6), 137-153. https://doi.org/10.34104/cjbis.021.01370153 @ @ 